\title{
Muatan Ideologi Iklan Global Pada Tayangan Media Televisi di Indonesia
}

\author{
Agung Eko Budiwaspada
}

Fakultas Senirupa dan Desain ITB

\begin{abstract}
This study tries to uncover the existence of ideological values that are present in the global advertisement in Indonesia, by focusing on how these ideological values are present in the communication ideas of global advertisements. It is aimed to respond to the whole factual problem using a series of analysis. At first, the meaningful expression of objects are identified, especially those that are related to the thoughts, perceptions, concepts, and objectives of global expressions in the advertisements. The interpretation norm of semiotic approach was employed to identify the ideological values of those global advertisements in Indonesia. Results indicate that global advertisements in Indonesia are loaded with ideological values. It is reflected in the appearances of those advertisements, including the swinging values of consumerism, cultural imperialism, stereotyping global lifestyles, perfectionism, and decontextualism. Although these embedded values are-somewhat-contradicting Indonesian values, they may emerge through dis-culturation, inculturation, and acculturation processes as there are no adequate efforts to make the public aware. This may lead to a big sacrifice that we all have to endure, and that is the emergence of high-cost culture.
\end{abstract}

Keywords: ideology; global advertisement; semiotics.

\section{Pendahuluan}

Wacana globalisasi kini menjadi topik perhatian yang tidak terelakkan. Dalam perkembangan mutakhir, muncul pembicaraan tentang potensi lenyapnya batas antarnegara dalam konteks komunikasi dan perdagangan. Dampak hal itu diperkirakan akan terasa dalam segala aspek kehidupan, termasuk politik, sosial, dan budaya. Globalisasi menunjukkan fenomena 'pengerutan dunia' dan peningkatan 'kesadaran akan dunia'. 'Pengerutan dunia' dapat dipahami dalam konteks institusi modernitas, sedangkan "meningkatnya intensitas kesadaran tentang dunia" lebih cenderung dilihat dalam konteks kultural [1]. Muncul anggapan bahwa dunia mengalami perubahan radikal dalam tatanan sosial. Berbagai bentuk kebudayaan modern yang dulu diandalkan, kini terasa tidak lagi memadai dihadapan ketidakpastian akibat globalisasi tersebut.

Selain itu, globalisasi juga mendorong terjadinya percampuran antarbudaya bangsa, melalui proses hegemoni antara budaya dominan dan budaya lemah, kemudian dikenal sebagai sub-culture. Proses hegemonisasi tersebut kemudian

Received June 12 $2^{\text {th }} 2007$, Revised August $6^{\text {th }}$ 2007, Accepted for publication August $24^{\text {th }} 2007$. 
melahirkan budaya superfisial, berupa budaya 'dangkal' hasil kutipan-kutipan pragmatis dari sejarah kolektif [2]. Percampuran budaya antarbangsa itu melahirkan istilah 'hibridasi budaya', situasi demikian kemudian dikenal sebagai chaotic culture.

Dalam globalisasi perdagangan di atas, barang komoditi kerap diartikan sebagai segala sesuatu yang diperjualbelikan dan beredar sebagaimana layaknya analogi "orbit" dalam medan "gravitasi". Gravitasi dinalogikan sebagai daya tarik produk, berputar tidak terbatas pada kawasan teritorial atau wilayah negara tertentu, melainkan mampu menembus batas-batas antarnegara, antarbenua, bahkan mendunia. Barang komoditi yang demikian kemudian mendapat predikat merk sebagai barang yang mendunia. Untuk melakukan penetrasi pasar, produsen masa kini memanfaatkan iklan yang menginformasikan pesan penjualan kepada masyarakat dunia. Iklan yang bersifat mendunia tersebut didefinisikan sebagai iklan yang menggunakan konsep pasar internasional, meskipun dari segi kreatifnya kerap diadaptasi bersama budaya lokal.

Perkembangan teknologi media, mengantarkan masyarakat untuk memasuki era padat informasi. Kemudian diikuti oleh membanjirnya sarana pengolah data informasi, tidak lagi sepadan dengan kemampuan manusia untuk menyerapnya. Begitu juga yang terjadi pada bidang periklanan, dalam kurun waktu tertentu, konsumen dipersuasi oleh begitu banyak pesan iklan. Dalam situasi seperti itu, tayangan iklan berusaha merebut perhatian calon konsumen dengan menampilkan keunikan desain. Dijumpai fakta, dalam upaya merebut perhatian masyarakat, konsep kreatif komunikasi iklan kerap mendramatisasi berbagai cuplikan yang merepresentasikan realitas sosial masyarakat. Dramatisasi kehidupan sosial tersebut selanjutnya disajikan kembali melalui bahasa iklan yang dilakukan secara terus menerus dalam media, sehingga merubah persepsi masyarakat terhadap objek iklan tersebut.

\section{Pendekatan}

Untuk mengupas permasalahan di atas, diperlukan cara memandang desain sebuah iklan melalui model pengungkapan makna yang menyertai objek visual iklan tersebut. Dalam hal ini, iklan dapat dipandang sebagai sebuah tanda. Tanda yang dimaksud adalah objek visual yang mengandung aspek pemikiran, persepsi, konsep, dan pesan. Tanda visual itu dikaji berdasarkan jenis, makna dan juga interpretasi budaya.

Objek yang dijadikan sebagai fokus kajian dalam tulisan ini dipilih dengan menggunakan cara internal sampling. Melalui cara ini, peneliti dapat menetapkan sampel yang akan dikaji kemudian dipilih 5 (lima) desain iklan yang bersifat mendunia dan ditayangkan oleh media televisi di Indonesia. Iklan 
tersebut yaitu iklan kartu kredit Citibank, iklan rokok Marlboro, iklan minuman ringan Pepsi Cola, iklan pelembab wajah L'Oreal, dan iklan telepon selular Nokia. Iklan-iklan tersebut dipilih berdasarkan relevansinya dengan persoalan nilai ideologis, popularitas, serta frekuensi tayang yang tinggi pada media televisi dalam kurun waktu tahun 2000.

\section{Muatan Ideologi dalam Iklan Global}

Untuk mengidentifikasi nilai ideologis yang tersembunyi di dalam pesan iklan, dimulai dengan membahas unsur tanda visual berikut penafsiran makna, hingga pada tingkatan tertentu, guna mengungkap nilai ideologis yang dikandungnya. Kajian pada tingkat pertama, menganalisis tata ungkap iklan global, yakni komponen pokok iklan yang berupa tanda visual: mencakup figur (model iklan), benda (produk), warna, tipografi, dan gerak. Pembahasan juga diarahkan pada interaksi antara tanda dengan yang ditandainya secara lebih luas. Pada tingkat ini mulai tampak berhubungan dengan cerita atau kiasan dari citra.

Kajian pada tingkatan selanjutnya (tingkat kedua), berpijak pada hasil kajian tingkat pertama, pembahasan diarahkan untuk menguraikan bagaimana nilainilai ideologis dalam iklan global. Hal ini dinilai penting untuk dikaji karena iklan merupakan suatu bentuk komunikasi yang tidak dapat berdiri sendiri di tengah dinamika kultural. Selain itu, periklanan sendiri adalah salah satu bentuk budaya yang amat populer dan merefleksikan kebutuhan kehidupan manusia sehari-hari. Iklan berada di mana-mana yang merupakan bagian dari kehidupan manusia modern [3].

\subsection{Konsumerisme dan Gaya Hidup}

Konsumerisme adalah suatu paham dan gaya hidup yang menganggap barangbarang (mewah) sebagai ukuran kebahagiaan dan kesenangan. Atau dalam arti kata yang lain, konsumerisme dapat dikatakan sebagai suatu gaya hidup tidak hemat [4].

Iklan kartu kredit pada Gambar 1 menyajikan kolase kegiatan berbagai individu dalam memenuhi kebutuhannya. Digambarkan bahwa setiap individu mengambil benda yang dibutuhkannya hanya cukup dari sebuah tas yang terletak dilapangan terbuka. Individu yang ditampilkan mewakili profil masyarakat kelas atas, mulai dari balita hingga orang dewasa. Objek atau benda, disesuaikan dengan gaya hidup setiap individu yang mengambilnya. Dimulai dari seorang anak laki-laki mengambil seekor anjing, seorang wanita muda mengambil sepasang sepatu, seorang pria muda mengambil gitar elektrik, pengendara sepeda motor masing-masing mengambil kain dan mengisikan 
bahan bakar pada tangki kendaraannya, pelari mengambil kostum, pegolf mengambil stick golf, hingga seorang peselancar mengambil papan selancar.

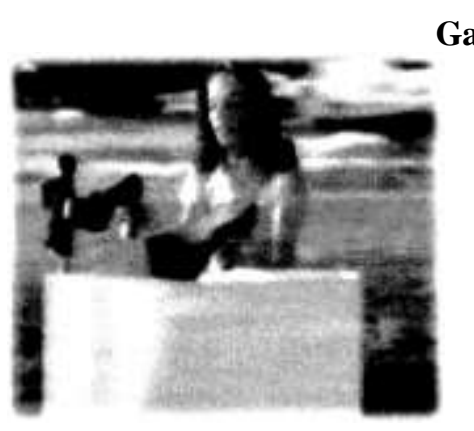

\section{Gaya Hidup Konsumtif}

Tayangan ini merupakan ikon yang memiliki makna denotatif (menggambarkan objek) sekaligus

mengandung makna konotatif (terutama pada figurfigur manusia) yang mengarahkan asosiasi masyarakat kelas atas, yakni sebagai kelompok sasaran pemasaran kartu kredit Visa. Ikon konotatif ini dapat dimengerti sebagai kode budaya.

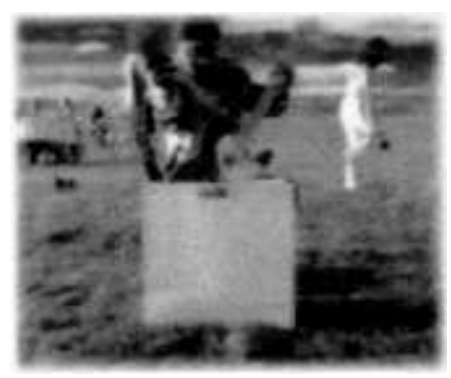

Gambar dirangkai dalam gerak lambat (slow motion), sehingga memberi kesan berat dan serius. Gerak lambat dari seluruh iklan ini, menciptakan konotasi yang sebaliknya, yakni menggambarkan seluruh aktivitas berbelanja menggunakan kartu Visa silih berganti tiada henti.
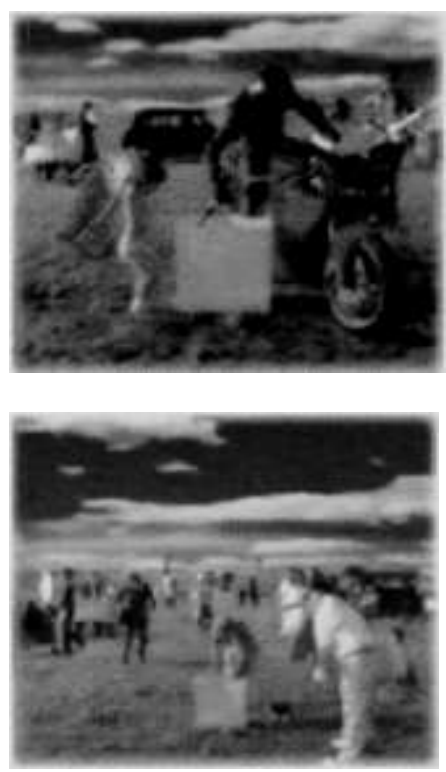

Benda-benda yang ditayangkan merupakan tanda yang bersifat konotatif. Pertukaran produk tampak lebih terstruktur, baik yang dibentuk oleh aspek 'ekspresif' maupun aspek 'simbolis' dalam tayangan. 


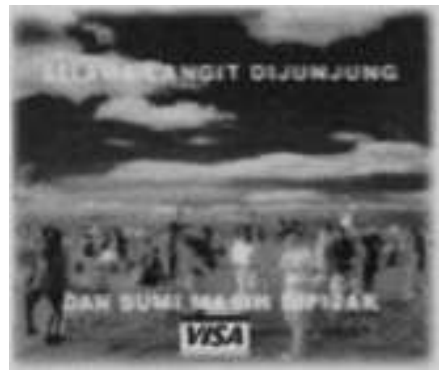

Catatan:

Iklan Kartu Kredit visa ini merupakan bentuk iklan global yang diadaptasi melalui copytext edit.
Selain sebagai ikon yang merepresentasikan objeknya, warna biru (langit) dan kuning kecoklatcoklatan (daratan) merupakan tanda yang bersifat konotatif mencerminkan warna identitas perusahaan Visa Card. Sedangkan tampilan teks dan tipografi merupakan kode semantik yang menggambarkan luasnya jaringan dan lamanya masa berlaku kartu ini.

\author{
Aspek Budaya: \\ Dalam tayangan terdapat proses inkulturasi budaya \\ yang ditandai oleh perubahan budaya uang kertas ke \\ budaya 'uang plastik'. Selain itu tumbuhnya budaya \\ berhutang sebagai sebuah gengsi baru. Budaya \\ semacam ini telah tumbuh di masyarakat perkotaan \\ Indonesia.
}

\section{Aspek Ideologi:}

Nilal-nilai konsumtif telah menjelma dalam bentuk fetisisme komoditi.

\section{Gambar 1 Iklan kartu kredit Citibank.}

Mencermati iklan tersebut, dapat diperoleh suatu gambaran tentang gaya hidup masyarakat perkotaan di Indonesia. Semua kebutuhan bagi semua profesi dan semua umur dapat difasilitasi dengan mudah oleh sebuah 'uang plastik' yang kemampuan daya beli dan kemampuan daya jangkaunya luar biasa leluasa. Sebagian besar masyarakat perkotaan kelas atas, telah akrab dengan budaya belanja semacam ini. Makna yang terkandung dalam iklan ini adalah penetrasi sikap kearah mulai menurunnya penghargaan terhadap uang tunai. Masyarakat kontemporer dirongrong untuk memenuhi segala kebutuhannya dalam skala prioritas yang kacau (tidak lagi homolog).

Lapisan makna terdalam dari iklan ini tidak hanya kebebasan dalam memperoleh seluruh kebutuhan seseorang, melainkan menyodorkan sebuah 'kesadaran semu' yang jalinan prosesnya mengkonsumsi 'uang plastik'. Aspek fetisitas, dimunculkan lewat daya pesona sebuah kartu kredit yang berfungsi sebagai alat bayar, serta mampu membayar apa saja dengan mudah, bahkan tanpa harus memiliki uang terlebih dahulu. Kartu kredit mendidik masyarakat untuk berhutang dengan mudah (kini berhutang telah menjadi gaya hidup yang bergengsi). 
Nilai konsumtif semakin tampak dalam iklan kartu visa, melalui ekspresi visual kegairahan berbelanja barang. Barang dikonsumsi tidak semata kebutuhan akan nilai-guna, melainkan cenderung untuk meningkatkan gengsi sosial. Hal ini lambat laun mengajak masyarakat kelas atas Indonesia cenderung untuk tidak hemat. Dalam budaya konsumtif, barang tidak lagi diartikan semata sebagai satu lalu lintas kebudayaan benda, akan tetapi sebagai sebuah 'panggung sosial', yang di dalamnya memperebutkan makna-makna sosial. Budaya konsumtif cenderung merupakan satu arena, di mana produk komoditas merupakan satu medium untuk membentuk personalitas, gaya, citra, dan cara mendiferensiasi status sosial. Produk komoditas, pada akhirnya menjadi sebuah cermin tempat para konsumen menemukan makna hidupnya [5].

\subsection{Imperialisme Budaya}

Imperialisme budaya dapat diartikan sebagai sebuah pandangan mengenai adanya kebudayaan asing yang lebih kuat serta mendominasi suatu golongan masyarakat, sehingga warganya kehilangan kepribadian dan identitasnya .

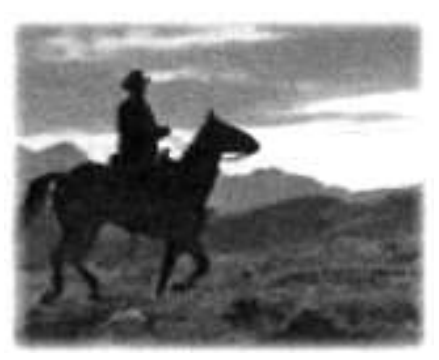

\section{Imperialisme Budaya}

Tayangan koboy berkuda merupakan ikon sebagai representasi objek. Hari senja menjelang malam dapat dikategorikan sebagai indeks.

Simbol tentang cowboy Amerika (kode budaya), dikenal mitos kebebasan cowboy Amerika dalam menghadapi ruang yang membentang luas.

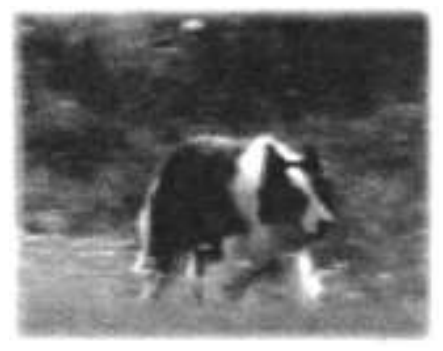

Tayangan seekor anjing merupakan ikon yang bersifat denotatif dalam merepresentasikan objek.

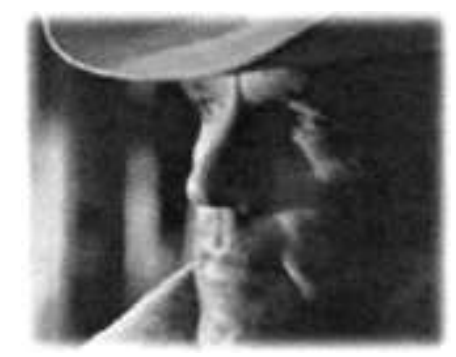

Tayangan wajah koboy merupakan mitos tentang kebaikan (tercermin dari ikon topi berwarna putih), keberanian (garis-garis wajah), kemandirian dan individualisme (dari pandangan matanya). 

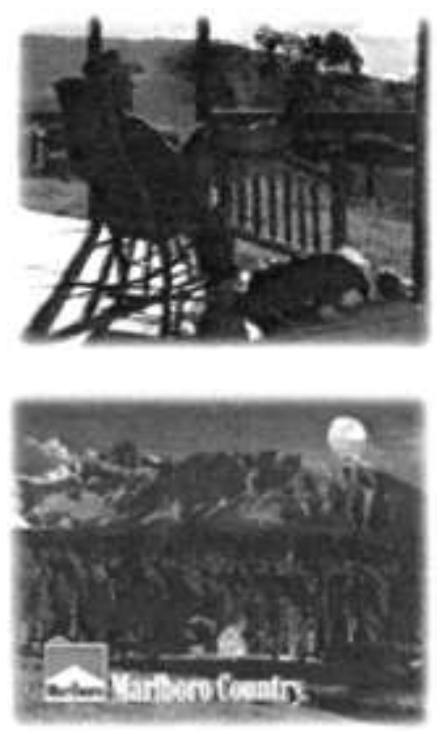

\section{Catatan:}

Iklan rokok Marlboro ini merupakan iklan global yang hadir di Indonesia tanpa proses adaptasi dengan kebudayaan setempat (iklan original)
Tayangan seorang koboy sedang duduk sendiri merupakan sifat individualisme yang melekat pada mitos koboy Amerika dan merupakan manifestasi kebebasan dari segala ikatan (tercermin pada sikap atau gesture)

Tayangan pemandangan perbukitan merupakan metafora 'Marlboro Country' yang merepresentasikan karakter alam Amerika .

\section{Aspek Budaya:}

Budaya individualisme Amerika Serikat sedikit demi sedikit mulai dipopulerkan dalam masyarakat perkotaan di Indonesia tayangan melalui iklan rokok.

\section{Aspek Ideologi:}

Tayangan iklan global yang ditayangkan seperti aslinya dapat dipandang sebagai imperialisme kultural ke negara lain.

Gambar 2 Iklan rokok Marlboro.

Iklan ini bercerita tentang potongan kehidupan (slice of life) seorang koboy. Cuplikan kehidupan yang diambil menggambarkan seorang koboy sedang mencari seekor anjing kesayangannya yang masih berada di alam terbuka pada saat senja hari. Kondisi ini membayangkan situasi yang sebenarnya membahayakan keselamatan, sementara kuda-kuda peliharaan telah kembali ke peternakan (ranch). Dalam proses pencarian tersebut, tergambar berbagai latar berupa pemandangan alam yang indah, gunung bersalju, langit memerah yang didramatisir oleh kehadiran burung-burung berterbangan, serombongan kuda berlarian, seekor rusa, serta keromantisan suasana ranch yang dimiliki oleh koboy tersebut. Setelah anjing diketemukan, dibawa kembali ke ranch, tampak gerak seorang koboy yang merasa puas. Adegan akhir iklan ini adalah menggambarkan suasana santai seorang koboy dalam menikmati panorama lingkungan peternakan di senja hari. 
Dalam tayangan iklan tersebut, terdapat mitos tentang koboy yang melambangkan semangat orang-orang Amerika. Dari segi visual dapat diidentifikasi bahwa seorang koboy menjalani hidupnya dekat dengan alam. Seorang koboy digambarkan bagai seorang yang peduli terhadap keharmonisan, terutama sikap dalam memperlakukan dan mengekspresikan rasa kecintaan terhadap binatang.

Koboy memiliki mitos sebagai karakter jiwa penakluk, dan melambangkan impian orang Amerika terhadap kebebasan, tentang ruang yang membentang luas, dan tentang manusia melawan cuaca. Dalam iklan rokok Marlboro terlihat bahwa seorang koboy seringkali sendirian yang merefleksikan sikap individualisme Amerika.

Melalui jaringan tayang yang luas tanpa disadari, iklan ini menawarkan kebudayaan Amerika pada masayarakat dunia. Unsur individualisme, ambisi untuk mengatur dan dorongan ingin menguasai diungkapkan dalam: "Come to Marlboro Country". Ungkapan ini, lambat laun membudaya dalam masyarakat pemirsa di seluruh dunia. Padahal di Amerika sendiri tengah menggalakkan kampanye anti rokok bagi masyarakatnya, tetapi justru Amerika mengekspor rokok secara besar-besaran ke berbagai negara berkembang sebagai perimbangan laju produksi Marlboro yang kehilangan pangsa pasar di dalam negeri sendiri .

Hegemoni budaya semacam itu terjadi tidak hanya melalui iklan rokok saja, tetapi terjadi pada pelbagai bentuk kegiatan lain, seperti pada budaya mengkonsumsi makanan, yang oleh Naisbitt disebut sebagai imperialisme dapur. Sebagian orang Amerika mengagumi wirausaha para pembuat fast food AS. Namun, masyarakat Amerika yang sadar akan kesehatan, cenderung khawatir dampak negartifnya terutama terhadap ekspor makanan yang kaya akan lemak, kolesterol, dan natrium ke negara lain ketika orang Amerika sendiri berusaha membatasi makanan seperti itu [6]

\subsection{Stereotip Gaya Hidup}

Secara umum istilah stereotip merupakan penandaan terhadap kelompok tertentu karena adanya anggapan dari individu terhadap kebiasaan perilaku anggota masyarakat menjadi sesuatu yang telah diterima , meskipun adakalanya anggapan tersebut tidak benar adanya. Oleh karenanya stereotip diartikan sebagai konsepsi mengenai sifat suatu golongan berdasarkan penilaian yang subjektif [7]. 


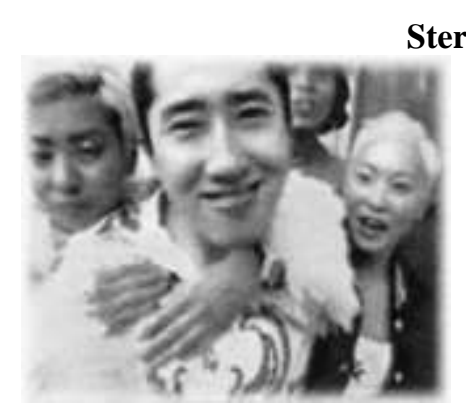

\section{Stereotip Gaya Hidup Global}

Wajah orang Cina sebagai ikon yang merepresentasikan objek. Tampilan orang Cina dengan gaya hidup kontemporer merupakan kode budaya.

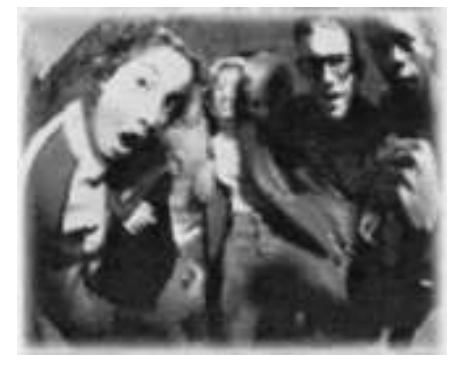

Wajah orang barat sebagai ikon yang merepresentasi objek. Wajah Barat mengekspresikan konotasi kuat tentang trend stereotipe gaya global (lihat ekspresi figur manusia)

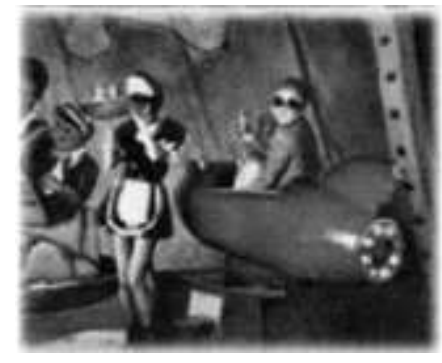

Segi stereotipe dapat diamati pada tayangan 'game station' yang sedang menjamur di seluruh dunia.

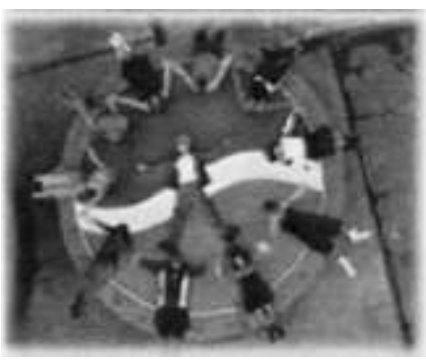

Tayangan ini merupakan kode semantik yang menggeneralisir anak-anakldan remaja di seluruh dunia yang mengkonsumsi Pepsi-cola.

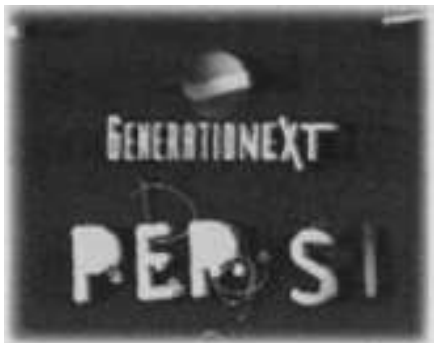

Aspek simbolik ditayangkan berupa bahasa verbal yang konotatif tentang lahirnya generasi 'Pepsi-cola' sebagai sebuah upaya membangun bentuk stereotipe anak muda modern 


\section{Catatan:}

Iklan Pepsi Cola merupakan iklan global tanpa penyesuaian dan perubagan (Iklan original)

\section{Aspek Budaya:}

Penyeragaman budaya (label gaya hidup generasi muda) dalam lingkup global.

\section{Aspek Ideologi}

Hegemoni budaya dalam bentuk pelabelan gaya hidup generasi muda masa depan

Gambar 3 Iklan minuman ringan Pepsi Cola.

Dalam iklan minuman ringan Pepsi Cola, unsur stereotip tampak pada unsur pelaku yang bersifat universal. Di dalamnya terdapat upaya penetrasi hegemoni, kelompok yang memiliki 'kuasa' menciptakan kepemimpinan budaya dengan cara penandaan terhadap kelompoknya, yakni sebagi generasi masa depan. Kemudian secara visual ditandai dengan keseragaman dalam gaya, perilaku, sikap, motivasi, hingga pada ujungnya keseragaman yang membuahkan stereotip dalam mengkonsumsi minuman.

Bentuk stereotip dalam perdagangan global, tergambar dari cara-cara mendoktrin masyarakat pemirsa melalui produksi makna. Iklan Pepsi Cola tidak semata menjual minuman ringan, melainkan turut menjual nilai-nilai stereotip gaya hidup yang ditawarkan dalam kemasan budaya melalui 'klaim' sebagai generasi masa depan. Ternyata produsen tidak semata menjual barang, akan tetapi secara tidak langsung mereka telah menjual pula makna.

\subsection{Perfeksionisme dalam Citra Diri}

Perfeksionisme merupakan watak atau sifat seseorang yang menganggap sesuatu yang tidak sempurna sebagal hal yang tidak dapat diterima. Perfeksionisme dikenal sebagal doktrin yang menyatakan bahwa kesempurnaan sifat moral seseorang menunjukkan ketinggalan derajatnya [8].

\section{Perfeksionisme dalam Citra Diri}

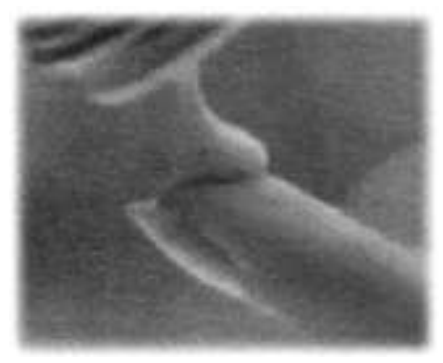

Tayangan detil ujung tangan menyentuh krim pelembab merupakan bentuk ikon yang bersifat denotatif dalam merepresentasikan objek 


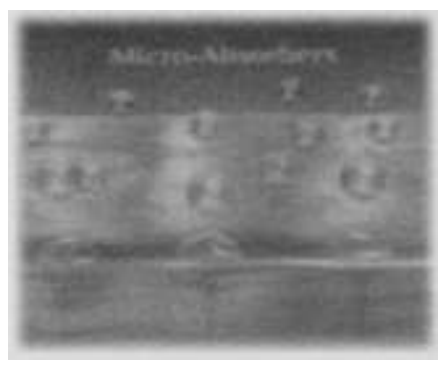

Simulasi proses kerja 'micro absorbers ketika melembabkan dan memutihkan wajah sebagai sebuah simbol konotatif dengan kode yang bersifat proairetik.

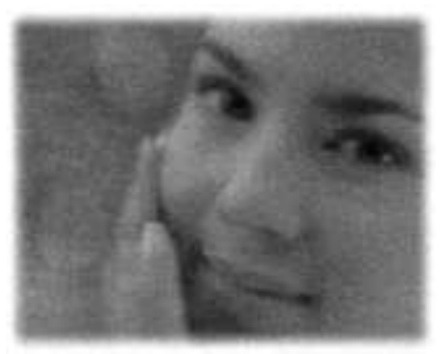

Tayangan close-up wajah pemeran utama berupaya menunjukkan kecantikan yang menjadi fetis kaum wanita.

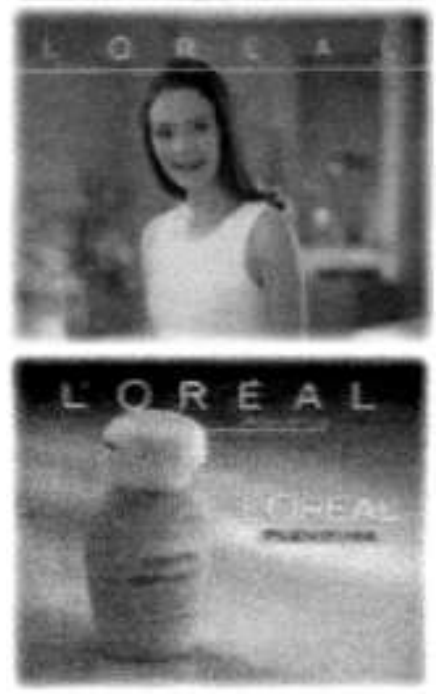

Tayangan sosok pemeran cantik yang sempurna ditampilkan sebagai simbol wanita yang memiliki perfeksionisme citra diri

\section{Catatan:}

Iklan Pelembab L'oreal merupakan iklan global yang yang telah disesuaikan untuk pemirsa lokal secara kreatif.

Tayangan kemasan produk kosmetik secara detil sebagai ikon yang bersifat denotatif dan merepresentasikan produk secara keseluruhan. Penayangan teks dan tipografi sebagai simbol yang konotatif yang menggiring pemirsa bahwa L'oreal adalah produk kosmetik global.

\section{Aspek Budaya:}

Budaya merawat diri dalam masyarakat modern di kota-kota besar diarahkan menjadi simbol status sosial

\section{Aspek Ideologi :}

Hipercare sebagai bentuk distorsi perfeksionistis

Gambar 4 Iklan cream pelembab wajah L'oreal. 
Dalam budaya modern wanita menempati peranan yang sama dengan pria dalam hal kesempatan memperoleh pekerjaan. Wanita dalam model iklan ini, dari segi penampilan dan tutur bahasanya merupakan produk budaya modern. Sosok wanita terpelajar dan berkemampuan ekonomi memadai, yang menjadi dasar atas kepedulian merawat kecantikannya. Paras wanita ini, mengindikasikan tipe wanita "Indo" yang menjadi idola masyarakat. Warna kulit yang putih, bersih, halus, dan tidak berminyak, merupakan kondisi ideal yang selalu dijadikan pusat opini dalam pembicaraan wanita. Realitas seperti ini ditanamkan terus-menerus oleh iklan televisi, kemudian secara bertahap memunculkan nilai-nilai kesempurnaan bagi wanita.

Dalam kepentingan perdagangan, kesempurnaan seringkali diupayakan dengan cara pencitraan dan menganalogikan norma kesempurnaan berdasarkan citra produknya. Pesan dalam bentuk komunikasi periklanan sering mendifinisikan kesempurnaan citra diri seseorang hanya dapat terwakili bila seseorang tersebut menggunakan atau memakai produk yang diiklankannya. Tren seperti itu merupakan akibat dari dominasi fantasi yang mengalahkan kodrati maupun ras. Dengan demikian pesan-pesan yang disampaikan oleh iklan krim pelembab seperti ini, menciptakan pergeseran pandangan terhadap ras sebagai sebuah kategori 'biologis' kepada ras sebagal kategori 'budaya' (estetis).

Di dalam dunia yang telah dikuasai oleh pelbagai macam komoditas kecantikan yang dipromosikan lewat tanda dan citraan dalam berbagai media periklanan, haikatnya telah mendistorsi pesan iklan. Iklan tidak lagi semata-mata memiliki peran konvensionalnya sebagai sarana komunikasi perdagangan, melainkan lebih sebagai ajang produksi konsep nilai. Bahkan sebuah kemasan body lotion di dalamnya mengandung konsep nilai-nilai tentang kesempurnaan wanita. Melihat kemasan yang ada serta media-media periklanan yang tersebar di manamana, terlihat bahwa penonjolan nilai-nilal kesempurnaan hampir selalu diarahkan pada orientasi akhir seputar perfeksionisme yang semu.

\subsection{Desakralisasi Mitos}

Desakralisasi mulai tumbuh subur dalam masyarakat kontemporer perkotaan di Indonesia melalui fenomena lunturnya pencitraan diri para pemimpin. Hal ini ditandai dengan banyaknya perilaku yang memiliki keterkaitan antara unsur visual dengan substansi peristiwa yang tidak relevan. Fenomena dekontekstualisasi semacam itu merebak dalam bentuk yang beraneka ragam, baik yang menyangkut perilaku sosial, maupun dalarn media-media informasi. Mitos tertentu dimanfaatkan untuk daya tarik pesan komoditas, padahal antara satu peristiwa dengan peristiwa lain keduanya tidak saling berkaitan. 


\section{Desakarilasasi Mitos}

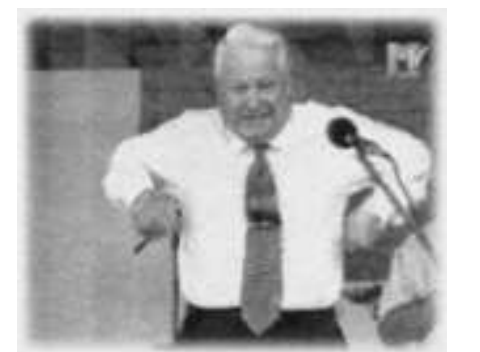

Tayangan iklan menampilkan kepala negara dan pemimpin negara adidaya (Rusia, Inggris, Amerika) yang awalnya dimitoskan oleh media.

Tingkah laku naif para tokoh secara sengaja ditonjolkan dalam rangka menciptakan sensasi sebagai bentuk perusakkan mitos kepresidenan maupun tokoh dunia.

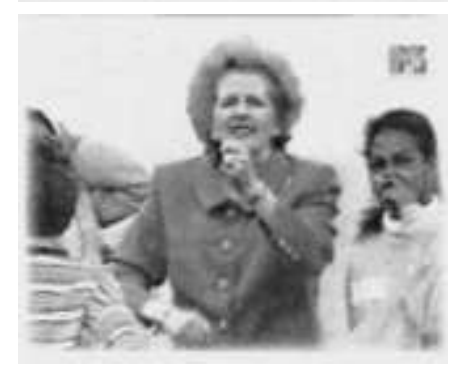

Tingkah laku naif ini ditayangkan secara terpengalpenggal dan dihadirkan pada konteks yang tidak berkaitan.

Dalam konteks penampilan visual, merupakan dekontekstualisasi.
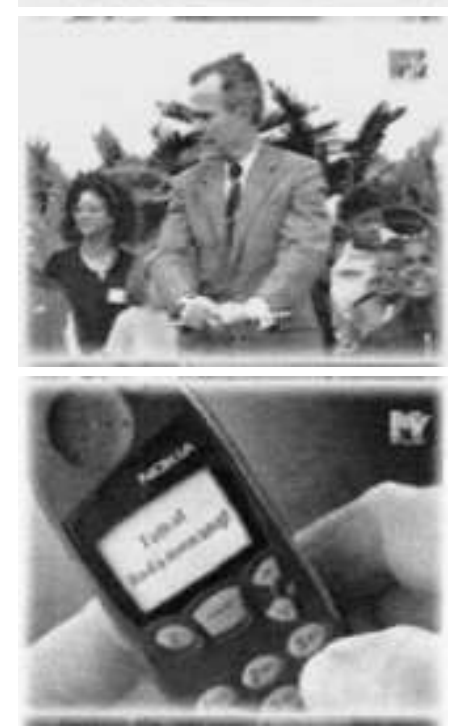

Tayangan gambar dengan fokus telepon selular merupakan ikon denotatif yang merepresentasikan penggunaan telepon selular. Sedangkan indeks yang bersifat konotatif ditampilkan dalam sosok manusia yang mengalahkan teknologi (ditunjang oleh simbol verbal: "Kami menyebutnya teknologi yang mengerti anda").

Terdapat ambiguitas (konflik dan kontradiksi) antara kecanggihan teknologi dengan aspek keunikan manusia

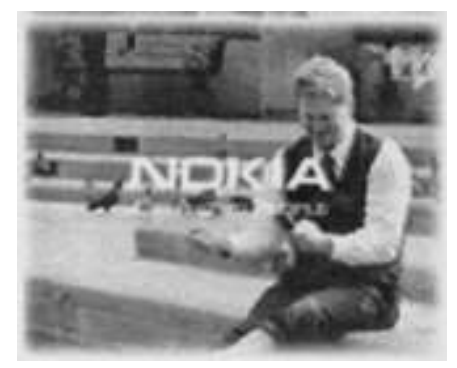

Ditayangkan presiden Amerika, Bill Clinton sedang gembira bermain game dalam telepon seluler, sebagai upaya mereduksi simbol yang selama ini menjadi mitos tentang kepresidenan. 


\section{Catatan:}

Iklan telepon selular Nokia merupakan iklan global yang telah diadaptasi dengan cara edit copytext

\author{
Aspek Budaya: \\ Terjadinya dekontekstualisasi dalam bentuk \\ demitosisasi menciptakan 'budaya permukaan' dan \\ degradasi penghargaan terhadap makna sosial.
}

\section{Aspek Sosial:}

Tercipta pengaburan peran dan pranata sosial.

Gambar 5 Semiotika iklan telepon selular Nokia.

Iklan di atas menyajikan kolase berbagai macam tingkah laku kekanak-kanakan dari berbagai figur dalam berbagai peristiwa. Digambarkan adegan-adegan mantan presiden Rusia, Boris Yeltsin menari di depan microphone, astronot berloncat-loncat di bulan, perempuan setengah baya juga berloncat-loncat di jalanan, sekelompok karyawan dan karyawati berteriak karena mendapatkan suatu yang dianggapnva 'surprise', seorang polisi menari-nari di jalanan, tiga orang eksekutif menendang bola, mantan perdana menteri Inggris Margaret Teacher bermain layang-layang, disusul oleh mantan presiden Amerika Serikat, George Bush juga bermain layangan, yang diakhiri oleh mantan presiden Bill Clinton bermain game di telepon selular Nokia di tepi kolam renang. Di sela-sela adegan-adegan tersebut muncul tulisan putih di atas dasar hitam dengan teknik cut to cut yang berbunyi:" Ada sifat kekanakan pada diri kita", "Itulah sebabnya ada game di ponsel kami", "Kami menyebutnya teknologi yang mengerti Anda".

Mencermati iklan ini diperoleh pemahaman tentang salah satu kecenderungan strategi komunikasi periklanan, yakni strategi yang mengeksploitasi tokoh terkenal sebagai daya tarik komoditas. Semakin terkenal seseorang, akan menghasilkan daya pesona dan trend setter yang semakin besar pula. Iklan ini telah memanfaatkan peluang tersebut, namun secara fragmentaris kehadiran figur-figur tersebut sesungguhnya tidak menunjukkan relevansi dengan konteksnya.

Iklan ini secara eksplisit mulai menunjukkan bagaimana konsep atau muatan nilai ideologi dekontekstualisasi dan disosialisasikan melalui iklan dalam bentuk demitosisasi. Salah satu dampak nyata dari dekontekstualisasi dalam bentuk demitosisasi ini, adalah menurunnya penghargaan terhadap perilaku masyarakat yang selama ini diagungkannya. Mitos tentang pemimpin didesakralisasi, kewibawaan presiden dipermainkan demi komoditas. 


\section{Simpulan}

Pertemuan dua kebudayaan atau lebih dalam wujud iklan hakikatnya merupakan tawar menawar tata nilai. Hal ini bagaimanapun akan mendatangkan akibat tertentu pada salah satu budaya. Akibat dari tawar menawar tata nilai ini paling tidak akan mengakibatkan terbentuknya tiga situasi budaya, yang akan memunculkan tiga situasi tata nilai. Ketiga situasi budaya atau tata nilai itu adalah: diskulturasi, inkulturasi dan akulturasi.

Diskulturalisasi merupakan keadaan yang terbentuk akibat perjumpaan antara budaya asli, 'tuan rumah', dengan budaya asing, 'budava luar', di mana nilai-nilai yang ada dalam kedua budaya itu saling menunjukkan karakter nilai yang berbeda atau tidak sejalan. Diskulturasi antara lain akan tercermin dalam bentuk konflik nilai yang dalam waktu tertentu akan memunculkan keadaan anomie (ketidakjelasan tata nilai), bahkan chaos (kekacauan tata nilai). Konflik nilai yang dihasilkan oleh proses diskulturasi, telah menggejala dalam masyarakat Indonesia. Ketidakjelasan atau kemenduaan sikap antara larut dalam budaya permukaan atau tetap berpegang teguh pada warisan nilai luhur, memicu kekacauan tata nilai.

Menelusuri nilai-nilai ideologis yang terkandung dalam iklan global di Indonesia, dapat diperoleh hubungan yang bermakna antara unsur nilai-nilai ideologis tersebut di atas. Nilai-nilai yang muncul menunjukkan ciri-ciri wacana dominan dalam globalisasi yang selanjutnya nilai-nilai tersebut berlaku hanya pada masyarakat perkotaan di Indonesia.

Ciri-ciri lain nilai-nilai ideologis menunjukkan adanya perubahan karakteristik ideologi. Bila pada pra-era globalisasi tradisi ideologi berlaku dalam sifat yang cenderung tetap untuk kurun waktu yang relatif lama, era globalisasi menunjukkan gejala yang justru berlawanan. Nilai-nilai ideologis pada saat ini cenderung bergerak dan berubah-ubah dalam dinamika kecepatan. Nilai-nilai ideologis silih berganti mempengaruhi masyarakat dengan segala kepentingannya melalui mekanisme dan jalinan proses naturalisasi ideologi yang didukung oleh teknologi informasi yang semakin hari semakin kondusif. Kecepatan silih-bergantinya nilai-nilai ideologis tersebut bagi sebagian besar masyarakat Indonesia mengakibatkan suatu kondisi yang disebut 'culture shock'. Situasi ini terjadi lantaran tidak adanya persiapan yang memadai terhadap berbagai kemungkinan dalam mengantisipasi wacana-wacana dominan akibat globalisasi tersebut. Sebuah pengorbanan yang besar akhirnva harus ditanggung untuk menebus ketidak siapan ini, yakni terciptanya fenomena budaya ekonomi biaya tinggi (high cost culture). 


\section{Daftar Pustaka}

[1] Barker, C. 2000. Cultural Studies: Theory and Practice. Sage Publications, London.

[2] Grossberg, L. 1987, The In-difference of Television, Journal of Communicationn Enquiry, 10(2).

[3] Waters, M. 1995. Globalization. Routledge, London

[4] Jefkins, F. 1996. Periklanan, (Terjemahan Haris Munandar). Erlangga, Jakarta.

[5] Williamson, J. 1991. Decoding Advertisment, Ideology And Meaning. Marion Bayars, London.

[6] Piliang, Y. 1998. Sebuah Dunia yang Dilipat. Mizan, Bandung.

[7] Jatman, D. 1996. Perilaku Kelas Menengah Indonesia. Bentang Budaya, Yogyakarta.

[8] Naisbitt, J \& Patricia A. 1990, Megatrend 2000, Binarupa Aksara, Jakarta. 